\title{
Effects of exposure and previous exposure to copper on growth of veliger larvae and survivorship of Mytilus edulis juveniles
}

\author{
K. Hoare, J. Davenport*, A. R. Beaumont \\ School of Ocean Sciences, University of Wales, Bangor, Menai Bridge, Gwynedd, Wales LL57 5EY, UK
}

\begin{abstract}
Exposure of Mytilus edulis L. (Mollusca: Bivalvia) to $8 \mathrm{ppb}\left(\mathrm{ppb}=\mu \mathrm{g} \mathrm{l}^{-1}\right.$ ) added copper during the veliger larval or post-larval (spat) stages has no significant effects on survivorship or shell growth. However, previous exposure to $8 \mathrm{ppb}$ added copper during the embryo stage significantly increases veliger growth rate and decreases spat survivorship in a population from the Menai Strait, Wales, UK, in which this level of copper causes a significant increase in embryo abnormality. No such effects of pre-exposure are seen in a population from the Westerschelde, The Netherlands, where $8 \mathrm{ppb}$ added copper does not constitute a stress on the embryo. These 'pre-incubation' (embryo exposure) effects far outweigh any direct influence of $8 \mathrm{ppb}$ copper exposure during the later stages and have a substantial effect on estimates of the toxicity of copper over the life cycle of $M$. edulis.
\end{abstract}

KEY WORDS: Mussels Larvae Copper Pollution - Pre-exposure - Long-term - Mytilus edulis - The Netherlands · United Kingdom

\section{INTRODUCTION}

Davenport \& Redpath (1984) reviewed the literature on the effects of copper on the mussel Mytilus edulis L. Copper is an essential element for Mytilus spp. but it is among the most toxic of metals when in excess (Viarengo 1989). An increase in copper concentration of $15 \mathrm{ppb}$ results in mortality of $50 \%$ of adult $M$. edulis in about 30 d (Manley 1980). Relatively unpolluted coastal waters have copper levels within the range 2 to $5 \mathrm{ppb}$ (Davenport \& Redpath 1984; ppb = $\mu \mathrm{g}^{-1}$ ), while concentrations of over about $30 \mathrm{ppb}$ are confined to the immediate locality of pollution sources (Lewis \& Cave 1982). Intracellular protective substances such as metallothioneins (Viarengo et al. $1980,1981 a, b, 1988,1989$, Roesijadi et al. 1982, Harrison et al. 1988) act by removing copper from solution by forming relatively stable, insoluble complexes with it.

\footnotetext{
- Current address: University Marine Biological Station, Millport, Isle of Cumbrae, Scotland KA28 OEG, UK
}

Exposure of mussels to low levels of copper can increase their resistance to higher copper concentrations (Davenport \& Manley 1978, Roesijadi \& Fellingham 1987), probably by stimulating the synthesis of metallothionein (Viarengo et al. 1980, Viarengo 1989).

Embryo development appears to be the most coppersensitive stage in the life cycle of Mytilus edulis $s_{i}$ the $\mathrm{EC}_{50}$ ('50\% Effective Concentration', the concentration which causes a $50 \%$ reduction in the specified parameter within the specified period) for production of normal ' $\mathrm{D}$ ' larvae has been estimated to be $5.8 \mathrm{ppb}$ added copper by Martin et al. (1981) and $7.9 \mathrm{ppb}$ added copper by Barnes (1989)

The veliger larva has the highest resistance to copper of any stage in the life cycle of Mytilus edulis, exhibiting a $15 \mathrm{~d} \mathrm{LC}_{50}$ ('50\% Lethal Concentration', the concentration which causes $50 \%$ mortality within the specified period) of $500 \mathrm{ppb} \mathrm{Cu}$ and a growth rate $\mathrm{EC}_{50}$ of about $200 \mathrm{ppb} \mathrm{Cu}$ (Beaumont et al. 1987). The reduction in copper tolerance to the adult level is gradual and completed when a shell length of about $5 \mathrm{~mm}$ is reached (Hoare \& Davenport 1994). Sub-lethal effects occur at much lower concentrations; Beaumont 
et al. (1987) found a small but significant reduction in veliger shell growth at 20 ppb added copper.

Ringwood (1992) found evidence for physiological adaptation of veligers of the bivalve Isognomon californicum to cadmium exposure and suggested that this was due to metallothionein induction. Inheritance and induction of copper metallothioneins in the embryos and veligers of Mytilus edulis have yet to be investigated. Roesijadi et al. (1982) exposed mature $M$. edulis to mercury for 2 wk just prior to spawning and found mercury metallothioneins in the resulting ' $\mathrm{D}$ ' larvae, but, since a small amount of mercury was found to have been passed on to the larvae, there is some uncertainty as to whether this metallothionein was inherited or autogenous.

One aim of the experiments described in this paper was to provide information on possible differences in physiological response to copper challenge among populations of Mytilus edulis which have differing pollution exposure histories. In order that the results might be relevant to the situation in the field, longterm experiments were carried out using a level of copper within the range reported for coastal waters (Lewis \& Cave 1982)

\section{MATERIALS AND METHODS}

Cultures. The treatment regimes (Table 1) began just after fertilisation; the embryo is the most pollutionsensitive stage in the life cycle of Mytilus edulis (Martin et al. 1981) and therefore would probably be under the greatest selection pressure. The treatment regimes were designed to allow the effects of copper treatment at each stage on that and subsequent stages to be evaluated. There were 2 replicate cultures ( $a$ and $b$ ) per treatment group.

The source populations were chosen from sites where Mytilus edulis occurs intertidally in the absence of the closely related hybridising species $M$. galloprovincialis and $M$. trossulus Gould. (Gosling 1992) The 'clean' site source population was from Gallows Point $\left(53^{\circ} 15^{\prime} \mathrm{N}, 4^{\circ} 06^{\prime} \mathrm{W}\right)$, Menai Strait, Wales, UK, a

Table 1. Copper exposure at 3 stages of development of 6 treatment groups of laboratory-reared Mytilus edulis. +: copper exposure; -- control conditions

\begin{tabular}{llllllll}
\hline $\begin{array}{l}\text { Developmental stage } \\
\text { (duration) }\end{array}$ & \multicolumn{7}{c}{ Treatment group } \\
\hline Embryo $(3 \mathrm{~d})$ & 2 & 3 & 4 & 5 & 6 \\
Veliger $(3-4 \mathrm{mo})$ & - & - & - & + & + & + \\
Post-settlement $(4-5 \mathrm{mo})$ & - & + & + & - & + & + \\
\hline
\end{tabular}

relatively uncontaminated open coast site without significant riverine influence. The 'polluted' site source population was from Veerhaven $\left(51^{\circ} 26^{\prime} \mathrm{N}, 4^{\circ} 03^{\prime} \mathrm{E}\right)$, Westerschelde, The Netherlands. The Westerschelde, part of the Rhine-Meuse delta system, forms the estuary of the River Schelde. Mussels from Veerhaven and other sites in the Westerschelde have been shown to have high tissue concentrations of mercury, lead, chromium, arsenic, nickel, cadmium, copper, zinc (Luten et al. 1986, Stronkhorst 1992), polychlorinated biphenyls (PCB) and pesticides (Hummel et al. 1990, Stronkhorst 1992).

All experiments were carried out in accordance with the provisions of the Sea Fisheries (Shellfish) Act 1967 as varied by the Molluscan Shellfish (Control of Deposit) (Variation) Order 1983, S.I. no. 159.

Menai Strait and Westerschelde veliger cultures spawned on 16 July 1991 and 13 July 1990, respectively, were grown on to settlement using the methods of Bayne (1965); see Hoare et al. (1995; this issue) for details of the spawning techniques and embryo cultures.

For each veliger culture, up to 20000 normal $3 \mathrm{~d}$ old larvae ('D' larvae) were transferred to a sterilised glass $5 \mathrm{l}$ beaker to give about 5 ' $\mathrm{D}$ ' larvae $\mathrm{ml}^{-1}$, with varying proportions of abnormal 3 d old larvae. Pavlova lutheri (Droop) Green and Rhinomonas reticulata (Lucas) Novarino were added to give 40 and 10 cells $\mu l^{-1}$ respectively.

Copper (as $\mathrm{CuCl}_{2} \cdot 2 \mathrm{H}_{2} \mathrm{O}$ ) solution was diluted with $0.2 \mu \mathrm{m}$ filtered UV-sterilised seawater (FSW) before being added to the appropriate treatment groups to give a concentration of $8 \mathrm{ppb}$ added copper in these groups; all other treatment groups were exposed to background copper levels (approximately $3 \mathrm{ppb}$ throughout the course of the experiment). The larvae were grown on using standard larval rearing methods (Beaumont et al. 1988). At the start of the experiments potentiometric stripping analysis (Jagner 1982, Redpath 1985) was used to verify that the actual copper concentrations achieved were similar to the desired levels. The results of this analysis indicated that the copper-treated cultures were, on average, exposed to $7.3 \mathrm{ppb}$ (standard deviation $5.4 \mathrm{ppb}$ ) Cu more than the control cultures, in agreement with Beaumont et al. (1987) who demonstrated that under standard larval rearing conditions copper levels do not fall by more than $25 \%$ during the intervals between changes. Significant early mortality is a common feature of Mytilus edulis veliger cultures, and the larvae were therefore counted again when they were $2 \mathrm{wk}$ old and the culture volumes adjusted to maintain 5 normal larvae $\mathrm{ml}^{-1}$.

The shell lengths of the mussels in all of the cultures derived from one of the source sites were assessed using the photomicrographic method of Beaumont \& 
Budd (1982) when the first pediveligers appeared in the fastest growing culture derived from that site.

The cultures were reared through and beyond metamorphosis as follows. Each culture was transferred to a sterilised, high-sided, $170 \mu \mathrm{m}$ mesh, plastic sieve which fitted closely into the 5 l glass beaker This allowed settled and unsettled larvae to be kept in the same culture (Beaumont et al. 1988). FSW, copper and algal rations were renewed 3 times per week as previously, except that algae were supplied at double the previous concentrations. Those larvae not retained by the $170 \mu \mathrm{m}$ sieve were retained during changing in a $45 \mu \mathrm{m}$ sieve as before.

When fewer than $1 \%$ of the larvae still passed through the $170 \mu \mathrm{m}$ sieves (at an age of about $8 \mathrm{wk}$ ) these sieves were transferred from the $5 \mathrm{l}$ glass beakers to sterilised $20 \mathrm{l}$ plastic crates, such that each crate held 3 sieves at the appropriate copper concentration. This transfer to crates facilitated water changing, which continued to be carried out 3 times per week. Pavlova lutheri and Rhinomonas reticulata continued to be supplied at 80 and 20 cells $\mu l^{-1}$ respectively.

When it appeared that all mussels within each sieve had settled and reached a shell length of at least $500 \mu \mathrm{m}$ (at an age of about $3 \frac{1}{2} \mathrm{mo}$ ), the cultures were subjected to the final set of conditions (Table 1). They were grown on in these conditions until they reached a mean size of about $3 \mathrm{~mm}$, a total culture duration of about $8 \mathrm{mo}$. The effect of treatment on survivorship to this time was estimated but counts were only made where there was a visible difference in survivorship between treatments

Data analysis. Where possible, analysis of variance (Sokal \& Rohlf 1981) was used to test the raw or transformed data for statistical significance. Where data did not fit the assumptions for parametric analysis the nonparametric Kruskal-Wallis and Mann-Whitney tests (Siegel 1956) were used.

\section{RESULTS}

\section{Menai Strait}

Although there was significant variation in survivorship between replicates within treatments, there were no significant effects of treatment on mortality between 3 and $13 \mathrm{~d}$ old. Mean overall survivorship was $35 \%$. No increase in the number or size of empty shells, i.e. in mortality, was observed during the remainder of the veliger stage.

The shell length measurements (Table 2) indicated that there was a significant $(p<0.05)$ difference between treatments in size at $27 \mathrm{~d}$ old, above and
Table 2. Mytilus edulis. Mean shell lengths of Menai Strait veliger larvae cultured under different copper exposure regimes. The standard deviations are given in parentheses. $a$ and $b$ are replicate cultures. Measurements were taken when the cultures were $27 \mathrm{~d}$ old from photomicrographs and were of between 13 and 94 larvae per culture. For further explanation of treatment regimes see Table 1

\begin{tabular}{|c|c|c|}
\hline Treatment & Culture & $\begin{array}{l}\text { Shell length } \\
(\mu \mathrm{m})\end{array}$ \\
\hline \multirow[t]{4}{*}{ No copper } & $1 \mathrm{a}$ & $171(39)$ \\
\hline & $1 b$ & $148(30)$ \\
\hline & $2 a$ & $166(29)$ \\
\hline & $2 b$ & $188(34)$ \\
\hline \multicolumn{2}{|c|}{ Treatment mean: } & 170 \\
\hline \multirow[t]{2}{*}{$8 \mathrm{ppb} \mathrm{Cu}$ at veliger stage } & $3 a$ & $170(28)$ \\
\hline & $3 b$ & $161(37)$ \\
\hline \multicolumn{2}{|c|}{ Treatment mean: } & 165 \\
\hline \multirow[t]{2}{*}{$8 \mathrm{ppb} \mathrm{Cu}$ at embryo stage } & $4 a$ & $237(40)$ \\
\hline & $4 b$ & $178(31)$ \\
\hline \multicolumn{2}{|c|}{ Treatment mean: } & 214 \\
\hline \multirow{4}{*}{$\begin{array}{l}8 \mathrm{ppb} \mathrm{Cu} \text { at both embryo } \\
\text { and veliger stages }\end{array}$} & $5 a$ & $187(38)$ \\
\hline & $5 b$ & $180(41)$ \\
\hline & $6 a$ & $215(33)$ \\
\hline & $6 b$ & $198(49)$ \\
\hline \multicolumn{2}{|c|}{ Treatment mean: } & 200 \\
\hline
\end{tabular}

beyond the difference $(p<0.001)$ between replicates. This difference in growth rates was caused by after effects of different treatments during the embryo stage rather than by different treatments during the veliger stage itself. There was a significant $(p<0.05)$ difference between those groups which had identical treatments at the veliger stage but different copper treatments at the embryo stage. The mean shell length at $27 \mathrm{~d}$ old was $203 \mu \mathrm{m}$ for those which were exposed to $8 \mathrm{ppb}$ added copper as embryos but only $168 \mu \mathrm{m}$ for those which underwent embryonic development under control conditions. Cultures which had been exposed to $8 \mathrm{ppb}$ added copper during the veliger stage were on average slightly, but not significantly, smaller than those which were cultured at background copper levels during the veliger stage but which had experienced identical embryo treatments.

As mentioned above, there were no signs of differential mortality between treatments during the veliger phase. However, when these cultures had reached the spat stage there were obvious differences in spat densities between the treatments, and so at the end of the experiment the juveniles were counted (Table 3). The total survivorships are shown in Table 3. Analysis indicates that neither veliger nor post-settlement treatment had a significant effect on survivorship. However, copper exposure at the embryo stage caused significantly $(p<0.002$ ) increased mortality between the veliger stage and the end of the experiment. 
Table 3. Mytilus edulis. Survivorships to the end of the experiment in Menai Strait mussel cultures raised under different copper treatment regimes, given both as absolute numbers and as percentages of numbers surviving in the cultures at earlier stages. For further explanation of treatment regimes see Table 1

\begin{tabular}{|c|c|c|c|c|c|}
\hline \multirow[t]{2}{*}{ Treatment } & \multirow[t]{2}{*}{ Culture } & \multicolumn{4}{|c|}{ Survivorship } \\
\hline & & Number & $\begin{array}{c}\text { As } \% 13 \mathrm{~d} \text { old } \\
\text { veligers }\end{array}$ & $\begin{array}{l}\text { As \% 'D' } \\
\text { larvae }\end{array}$ & As $\%$ eggs \\
\hline \multirow[t]{3}{*}{ No copper } & $1 \mathrm{a}$ & 447 & 4.5 & 2.2 & 1.3 \\
\hline & $1 \mathrm{~b}$ & 1133 & 13.5 & 5.7 & 2.7 \\
\hline & Treatment mean: & 790 & 9.0 & 4.0 & 2.0 \\
\hline \multirow[t]{3}{*}{$8 \mathrm{ppb} \mathrm{Cu}$ post-settlement } & $2 \mathrm{a}$ & 700 & 12.7 & 3.5 & 1.7 \\
\hline & $2 b$ & 182 & 3.6 & 0.9 & 0.4 \\
\hline & Treatment mean: & 441 & 8.2 & 2.2 & 1.1 \\
\hline \multirow{3}{*}{$\begin{array}{l}8 \mathrm{ppb} \text { Cu post-settlement and } \\
\text { as veligers }\end{array}$} & $3 a$ & 509 & 5.7 & 2.5 & 1.2 \\
\hline & $3 b$ & 921 & 20.5 & 4.6 & 2.5 \\
\hline & Treatment mean: & 715 & 13.1 & 3.6 & 1.9 \\
\hline \multirow{3}{*}{$8 \mathrm{ppb} \mathrm{Cu}$ at embryo stage } & $4 a$ & 153 & 2.4 & 0.9 & 0.3 \\
\hline & $4 b$ & 62 & 1.1 & 0.3 & 0.1 \\
\hline & Treatment mean: & 107.5 & 1.8 & 0.6 & 0.2 \\
\hline \multirow[t]{3}{*}{$8 \mathrm{ppb} \mathrm{Cu}$ as embryos and velige } & jers & 138 & 1.8 & 0.7 & 0.3 \\
\hline & $5 b$ & 37 & 1.2 & 0.2 & 0.1 \\
\hline & Treatment mean: & 87.5 & 1.5 & 0.5 & 0.2 \\
\hline \multirow[t]{3}{*}{$8 \mathrm{ppb} \mathrm{Cu}$ at all stages } & $6 a$ & 48 & 0.6 & 0.2 & 0.1 \\
\hline & $6 b$ & 149 & 2.3 & 1.0 & 0.3 \\
\hline & Treatment mean: & 99 & 1.5 & 0.6 & 0.2 \\
\hline
\end{tabular}

Copper stress at the embryo stage appears to have far reaching effects. Mussel cultures which experience 8 ppb added copper as embryos grow faster during the veliger stage and suffer greatly increased mortality thereafter, probably during metamorphosis and settlement. These pre-incubation effects far outweigh any direct influence of copper exposure during these later stages

\section{Westerschelde}

There were no significant effects of treatment on survivorship to $14 \mathrm{~d}$ old, although there were significant differences $(p<0.01)$ among replicates within treatments. There were no signs of any additional mortality before settlement.

The length measurements (Table 4) taken at $19 \mathrm{~d}$ old indicate that there were no significant differences in size just before settlement.

As with the Menai Strait veliger cultures, those treatment groups which had experienced 8 ppb added copper during the veliger stage or control conditions during the embryo stage were always smaller than those which had experienced the alternative conditions at these stages, but which otherwise received identical treatment. However, these differences were not statistically significant. Survivorship to the end of the experiment was high in all cultures, with no differences apparent among the treatments, although no counts were made

\section{DISCUSSION}

No conclusions should be drawn from the large differences in mean growth rates of the control groups between the Menai Strait - and Westerschelde - derived laboratory populations because the experiments were carried out at different times and thus had differing water and food qualities in addition to the innate differences between the populations. It could be argued that the Menai Strait - and Westerschelde-derived laboratory populations were subjected to differing lengths of exposure to copper during the veliger stage because of their differing growth rates. However, they were exposed for the same developmental period. In order that both the duration and the developmental timing of exposure be constant, it is necessary to have identica] growth rates in differing cultures; this is a constant problem in studies of this type. In this case it was considered more reasonable to gear experimental exposures to developmental events than to imposed durations.

The effects of copper on the embryo stage of these cultures are detailed in Hoare et al. (1995)

The experiments do not display any significant direct effect of veliger exposure to $8 \mathrm{ppb}$ added copper on 
Table 4. Mytilus edulis. Mean shell lengths of Westerschelde veliger larvae cultured under different copper exposure regimes. The standard deviations are given in parentheses. Measurements were taken when the cultures were $19 \mathrm{~d}$ old from photomicrographs and were of between 36 and 119 larvae per culture. For further explanation of treatment regimes see Table 1

\begin{tabular}{|lrl|}
\hline Treatment & Culture & $\begin{array}{c}\text { Shell length } \\
(\mu \mathrm{m})\end{array}$ \\
\hline No copper & $1 \mathrm{a}$ & $225(15)$ \\
& $1 \mathrm{~b}$ & $214(23)$ \\
& $2 \mathrm{a}$ & $187(23)$ \\
& $2 \mathrm{~b}$ & $198(22)$ \\
& Treatment mean: & 206 \\
8 ppb Cu at veliger stage & $3 \mathrm{a}$ & $192(27)$ \\
& $3 \mathrm{~b}$ & $195(22)$ \\
& Treatment mean: & 193 \\
8 ppb Cu at embryo stage & $4 \mathrm{a}$ & $226(22)$ \\
& $4 \mathrm{~b}$ & $220(23)$ \\
& Treatment mean: & 223 \\
8 ppb Cu at both embryo & $5 \mathrm{a}$ & $209(19)$ \\
and veliger stages & $5 \mathrm{~b}$ & $210(23)$ \\
& $6 \mathrm{a}$ & $205(21)$ \\
& $6 \mathrm{~b}$ & $199(22)$ \\
& Treatment mean: & 206 \\
& &
\end{tabular}

veliger growth or on survivorship after the 'D'-larva stage

There is a significant difference between the Menai Strait and Westerschelde cultures in the effects of embryonic copper treatment on later growth and survivorship. It appears that where copper has exhibited a significant stress on the embryos of a culture, i.e. in the 8 ppb copper-treated Menai Strait cultures, the surviving population of morphologically normal ' $D$ ' larvae grow significantly faster $(\mathrm{p}<0.05)$ up to metamorphosis but then experience significantly higher mortality $(p<0.002)$. Such effects are not seen when embryos are exposed to $8 \mathrm{ppb}$ added copper where this does not appear to constitute a stress, i.e. in the Westerschelde cultures.

A possible hypothesis which might explain the Menai Strait results is that copper exposure at the embryo stage may have sub-lethal, or rather deferredlethal, effects, in addition to the short-term induction of lethal abnormalities. These effects might be in the form of damage to presumptive adult tissues, or might involve a modification of veliger physiology such that larvae lay down a lesser reserve of lipid, which would allow faster growth while leaving too little stored energy for the successful completion of metamorphosis. Ringwood (1992) showed that cadmium caused significant reductions in veliger mass growth of the Hawaiian bivalve Isognomon californicum at concentrations far lower than those required to produce a sig- nificant reduction in shell growth. Metamorphosis in Mytilus edulis appears to occur only when organic matter, i.e. tissue dry mass, attains a weight of over $45 \%$ of the total dry mass of the larva (Lucas et al. 1986). It is therefore possible that small increases in metal concentrations may affect metamorphosis. Some idea of the effects of copper at the different stages can be gained from the survivorships to the juvenile stage under different treatments. The magnitude of the lipid fraction of the pre-settlement dry weight would give an indication of the reserves accumulated to fuel metamorphosis (Holland \& Spencer 1973).

The effects of copper stress at the embryo stage on the later stages of the Menai Strait cultures meant that. although $8 \mathrm{ppb}$ added copper produced a mean abnormality/mortality of only $49 \%$ within the $3 \mathrm{~d}$ exposure period (Hoare et al. 1995), mean survivorship to the juvenile stage in these cultures was only $12 \%$ of that found in cultures which had experienced control conditions as embryos. Putative pollution selection in the Westerschelde for resistance to copper toxicity at the embryo stage may therefore also have important repercussions at later life stages.

The effect of copper treatment of Menai Strait Mytilus edulis embryos on later life stages appears to be an amalgam of reduced survivorship and hormesis (Stebbing 1982); $8 \mathrm{ppb}$ added copper causes faster cleavage (Hoare unpubl.), reduced embryonic normality, faster veliger growth and greatly reduced survivorship through metamorphosis to the juvenile stage, independently of later treatment. Such a fundamental effect of early treatment may indicate that copper affects the cytoplasmic maternal developmental determinants, which direct molluscan ontogeny. Pre-incubation effects, though considerable in this case, are little studied. Bayne (1972) found that nutritional stress on adult $M$. edulis led to increased rates of developmental abnormality in the offspring, perhaps because of reduced inheritance of energy (Bayne et al. 1978). Bayne et al. (1975) found that stress on parents reduced veliger growth rates, while Helm et al. (1973) found that the offspring of food-stressed oysters (Ostrea edulis) had reduced survivorship through metamorphosis and settlement, as well as reduced rates of veliger growth. These studies agree with the copper study described here in that factors which affect early development have long-reaching effects, but disagree in that they did not reveal any hormesis.

Acknowledgements. We thank Dr Herman Hummel and Roelof Bogaards of the Netherlands Institute of Ecology Centre for Estuarine and Coastal Ecology for kindly supplying mussels and pollution data from the Westerschelde. This study was funded by the Science and Engineering Research Council. 


\section{LITERATURE CITED}

Barnes, D. A. (1989). The effects of initial egg density and added copper concentration on the development of early larval stages of the mussel Mytilus edulis. M.Sc. thesis, University of Wales, Bangor

Bayne, B. L. (1965). Growth and the delay of metamorphosis of the larvae of Mytilus edulis (L.). Ophelia 2: 1-47

Bayne, B. L. (1972). Effects of stress on the adult on larval development of Mytilus edulis. Nature 237: 459

Bayne, B. L., Gabbott, P. A., Widdows, J. (1975). Some effects of stress in the adult on the eggs and larvae on Mytilus edulis L. J. mar. biol. Ass. U.K. 55: 675-689

Bayne, B. L., Holland, D. L., Moore, M. N., Lowe, D. M., Widdows, J. (1978). Further studies on the effects of stress in the adult on the eggs of Mytilus edulis. J. mar. biol. Ass. U.K. 58: 825-841

Beaumont, A. R., Beveridge, C. M., Barnet, E. A., Budd, M. D., Smyth-Chamosa, M. (1988). Genetic studies of laboratory reared Mytilus edulis I. Genotype specific selection in relation to salinity. Heredity $61.389-400$

Beaumont, A. R., Budd, M. D. (1982). Delayed growth of mussel (Mytilus edulis) and scallop (Pecten maximus) veligers at low temperatures. Mar. Biol. 71: 97-100

Beaumont, A. R., Tserpes, G., Budd, M. D. (1987). Some effects of copper on the veliger larvae of the mussel Mytilus edulis and the scallop Pecten maximus (Mollusca, Bivalvia). Mar. environ. Res. 21. 299-309

Davenport, J., Manley, A. (1978). The detection of heightened sea-water copper concentrations by the mussel Mytilus edulis. J. mar. biol. Ass. U.K. 58: 843-850

Davenport, J., Redpath, K. J. (1984). Copper and the mussel Mytilus edulis L. In: Bolis, L., Zadunaisky, J., Gilles, R. (eds.) Toxins, drugs and pollutants in marine animals. Springer-Verlag, Berlin, p. 176-189

Gosling. E. (ed.) (1992). The mussel Mytilus: ecology, physiology, genetics and culture. Developments in aquaculture and fisheries science 25. Elsevier, Amsterdam

Harrison, F. L., Lam, J. R., Novacek, J. (1988). Partitioning of metals among metal-binding proteins in the bay mussel, Mytilus edulis. Mar environ. Res. 24: 167-170

Helm, M. M., Holland, D. L., Stephenson, R. R. (1973). The effect of supplementary algal feeding of a hatchery breeding stock of Ostrea edulis L. on larval vigour. J. mar. biol. Ass. U.K. 53: 673-684

Hoare, K., Beaumont, A. R., Davenport, J. (1995). Variation among populations in the resistance of Mytilus edulis embryos to copper: adaptation to pollution? Mar. Ecol. Prog. Ser. 120: 155-161

Hoare, K., Davenport, J. (1994). Size-related variation in the sensitivity of the mussel, Mytilus edulis, to copper. J. mar biol. Ass. U.K. 74: 971-973

Holland, D. L., Spencer, B. E. (1973). Biochemical changes in fed and starved oysters, Ostrea edulis L. during larval development, metamorphosis and early spat growth. J. mar. biol. Ass. U.K. 53; $287-298$

Hummel, H., Bogaards, R. H., Nieuwenhuize, J., De Wolf, L., Van Liere, J. M. (1990). Spatial and seasonal differences in the PCB content of the mussel Mytilus edulis. Sci. tot. Environ. 92: 155-163

Jagner, D. (1982). Potentiometric stripping analysis: a review. Analyst 107: 593-599

Lewis, A. G. Cave, W. R. (1982). The biological importance of copper in oceans and estuaries. Oceanogr. mar. Biol. A Rev. 20: 471-695

Lucas, A., Chebab-Chalabi, L., Beninger, P. (1986), Variation

This artucle was presented by D. S. McLusky (Senior Editorial Advisor), Striling, $U K$ of relative organic matter in Mytilus edulis L. larvae and post-larvae. J. exp. mar. Biol. Ecol. 95: 99-103

Luten, J. B., Bouquet, W., Burggraaf, M. M., Rauchbaar, A. B., Rus, J. (1986). Trace metals in mussels (Mytilus edulis) from the Waddenzee, coastal North Sea and the estuaries of Ems, Western and Eastern Scheldt. Bull. environ. Contam. Toxicol. 36: 770-777

Manley, A. R. (1980). The responses of marine bivalves to selected heavy metals. Ph.D. thesis, University of Wales, Bangor

Martin, M., Osborn, K. E., Billig, P., Glickstein, N. (1981). Toxıcities of ten metals to Crassostrea gigas and Mytilus edulis embryos and Cancer magister larvae. Mar. Pollut. Bull. 12: 305-308

Redpath, K. J. (1985). Sub-lethal effects of trace metals on mussels. Ph.D. thesis, University of Wales, Bangor

Ringwood, A. H. (1992). Effects of chronic cadmium exposures on growth of larvae of an Hawaiian bivalve, Isognomon californicum. Mar. Ecol. Prog. Ser. 83: 63-70

Roesijadi, G., Calabrese, A., Nelson, D. (1982) Mercury-binding proteins of Mytilus edulis. In: Vernberg, W. B. Calabrese, A., Thurberg, F. P., Vernberg, F. J. (eds.) Physiological mechanisms of marine pollutant toxicity. Academic Press, New York, p. 75-87

Roesijadi, G., Fellingham, G. W. (1987). Influence of $\mathrm{Cu}_{1} \mathrm{Cd}$ and $\mathrm{Zn}$ preexposure on $\mathrm{Hg}$ toxicity in the mussel Mytilus edulis. Can. J. Fish. Aquat. Sci, 44: 680-684

Siegel, S. (1956). Non-parametric statistics for the behavioural sciences. McGraw-Hill, New York

Sokal, R. R., Rohlf, F. J. (1981). Biometry. The principles and practice of statistics in biological research, 2 nd edn. W. $\mathrm{H}$. Freeman \& Co., New York

Stebbing, A. R. D. (1982). Hormesis - the stimulation of growth by low levels of inhibitors. Sci. tot environ. 22 $213-234$

Stronkhorst, J. (1992). Trends in pollutants in blue mussel Mytilus edulis and flounder Platichthys flesus from two Dutch estuaries, 1985-1990. Mar. Pollut. Bull. 24: 250-258

Viarengo, A. (1989). Heavy metals in marine invertebrates: mechanisms of regulation and toxicity at the cellular level. Rev. Aquat. Sci. 1: 295-317

Viarengo, A., Canesi, L., Pertica, M., Mancinelli, G., Orunesu, M. Mazzucotelli, A., Bouquegneau, J. M. (1988). Biochemical characterization of a copper-thionein involved in Cu accumulation in the lysosomes of the digestive gland of mussels exposed to the metal. Mar. environ. Res. 24 $163-166$

Viarengo, A., Pertica, M., Canesi, L., Mazzucotelli, A., Orunesu, M., Bouquegneau, J. M. (1989). Purification and biochemical characterization of a lysosomal copper-rich thionern-like protein involved in metal detoxification in the digestive gland of mussels. Comp. Biochem. Physiol. 93C: $389-395$

Viarengo, A., Pertica, M., Mancinelli, G., Palmero, S. Zanicchi, G., Orunesu, M. (1981a). Synthesis of Cu-binding proteins in different tissues of mussels exposed to the metal. Mar. Pollut. Bull. 12: 347-350

Viarengo, A., Pertica, M., Mancinelli, G., Zanicchi, G., Orunesu, M. (1980). Rapid induction of copper-binding proteins in the gills of metal exposed mussels. Comp. Biochem. Physiol. 67C: 215-218

Viarengo, A., Zanicchi, G., Moore, M. N. Orunesu, M. (1981b). Accumulation and detoxication of copper by the mussel Mytilus galloprovincialis Lam.: a study of subcellular distribution in the digestive gland cells. Aquat. Toxicol. 1: $147-157$

Manuscript first received: June 6, 1994

Revised version accepted: December 6, 1994 